\title{
Os sertões proibidos da Mantiqueira: desbravamento, ocupação da terra e as observações do governador dom Rodrigo José de Meneses*
}

André Figueiredo Rodrigues História Social / FFLCH/USP

\section{RESUMO}

Os sertões da Mantiqueira eram considerados pela Coroa portuguesa área proibida ao povoamento e à exploração econômica. Entretanto, ao longo do século XVIII, essa região foi ocupada fortuitamente e à revelia da lei. Demonstrar os significados, à ocupação e o entendimento dos sertões como algo movediço e em constante alteração será o nosso objetivo inicial de análise. A seguir, analisaremos as maneiras utilizadas pelos moradores dos sertões para burlar as proibições de usufruto daquelas terras, destacando-se, sorrateiramente, as atividades empreendidas por José Aires Gomes. Por último, mostraremos as observações que o governador dom Rodrigo José de Meneses legou-nos de sua viagem àquelas paragens, a fim de normalizar as ocupações das terras proibidas da Mantiqueira.

Palavras-chave: Minas Gerais. Mantiqueira. Sertões. Ocupação da terra.

\section{ABSTRACT}

The hinterlands of Mantiqueira were considered by Portuguese Crown as a forbidden area to settlement and economical exploration. However, along the XVIII century, that area was occupied randomly and without consent of the law. Discuss such occupation of the hinterlands as something fluid and in constant alteration is our main concern in this article. It will be analyzed the ways by which the individuals overcame the prohibitions of usufruct of those lands, and in particular the activities of José Aires Gomes. Lastly, it will be discussed the notes written by the governor Rodrigo José de Meneses concerning to his trip to that region in order to normalize the land occupation in Mantiqueira. Keywords: Minas Gerais. Mantiqueira. Hinterlands. Land occupation. 
A história de Minas Gerais, na sua origem, é a história das catas de ouro e faiscação de diamantes pelos ribeirões e córregos que cortavam a região montanhosa dos matos gerais dos índios cataguás.

Desde o primeiro século após o descobrimento do Brasil, várias entradas foram feitas naquelas paragens: pelo Norte, vindos da Bahia; pelo Leste, do Espírito Santo; e pelo Sul, oriundas do Rio de Janeiro e principalmente de São Paulo. Nenhuma dessas incursões que andavam em busca de riquezas minerais ou caçando indígenas promoveram o povoamento do território. Pelo contrário, esta última atividade concorreu para o seu despovoamento com o deslocamento dos silvícolas aprisionados como escravos para as fazendas de São Paulo ou para as de criação de gado e/ou engenhos do Nordeste açucareiro.

A ocupação do território mineiro começou com a bandeira de Fernão Dias Paes, no último quartel do século XVII. O bandeirante, partindo de São Paulo, rumou sentido Norte em busca de esmeraldas. Apesar de ter achado turmalinas, nunca encontrou as esmeraldas que tanto procurou, a não ser em seus delírios de febre, que o fizeram "ver a serra resplandecente". Seu sonho, porém, levou aos primeiros achados auríferos e deu origem às próprias Minas Gerais.

A partir de 1674, com a "bandeira das esmeraldas", tiveram início as primeiras manifestações do povoamento por europeus e seus descendentes da atual área do Estado de Minas Gerais, sendo então fundados os primeiros núcleos de aldeamento e a abertura de caminhos que, com suas paragens e roças, permitiram aos viandantes descansar e conseguir alimentos e víveres para sua manutenção no ir-e-vir pelos sertões e brenhas então desconhecidos.

Somente na última década do seiscentos, com a descoberta de ouro por Antônio Rodrigues Arzão nos sertões do rio Casca (1692), teve início o verdadeiro povoamento de Minas Gerais ${ }^{1}$.

Nos últimos anos do século XVII começou a corrida do ouro para as minas. Em pouco tempo, os descobertos auríferos foram se enchendo de gente de toda parte, sobretudo da Bahia e do Rio de Janeiro, que eram as regiões mais populosas da América portuguesa naquela época, e também de Portugal. Em poucos anos, no território até então habitado por indígenas passaram a viver pessoas das mais diversas origens e procedências.

Os caminhos encheram-se de sertanistas e aventureiros, acendendo a cobiça geral de homens de todos os estamentos e profissões pela riqueza propiciada na extração aurífera. Houve um verdadeiro rush desenfreado e indisciplinado, como não se vira na história americana até aquele momento.

Surgiram da noite para o dia povoados ao longo de caminhos sinuosos ou junto às datas de mineração, destacando-se as vilas do ouro (Mariana, Ouro Preto, Sabará, São João del Rei, Caeté, Pitangui, Serro Frio e São José del 
Rei). Para abastecer essas aglomerações, desenvolveu-se uma intensa rede comercial, com produtos de primeira necessidade e artigos de luxo trazidos da região portuária do Rio de Janeiro e de outras capitanias, como São Paulo, Bahia, Pernambuco e Rio Grande (do Sul). Além da existência, desde os primeiros anos das Minas, de roças e paragens que se dedicavam à produção $\mathrm{e}$ escoamento de produtos agrícolas (alimentos e bebidas — notadamente aguardente), pastoris (bois, vacas e ovelhas) e têxteis (tecidos grosseiros), direcionados ao abastecimento interno da capitania mineira ${ }^{2}$.

\section{Os SERTÕES PROIBIDOS DA MANTIQUEIRA}

Com a intenção de coibir o contrabando do ouro por caminhos "não oficiais" e a existência de lavras imemoriais, o governo metropolitano mandou que se fechassem quaisquer trilhas e logradouros existentes nas imediações das áreas mineratórias, tornando algumas regiões “áreas proibidas” à ocupação. Foi o caso, por exemplo, dos sertões da Mantiqueira / sertões do Leste, na fronteira Sul da capitania de Minas Gerais ${ }^{3}$.

Nessa área proibiu-se a existência de sítios volantes e do trânsito de homens dispersos, sem ocupação definitiva. A denominação "áreas proibidas” foi criada em 1736 pelo Bando de Aditamento ao Regimento de Minerar, que proibia que se lançassem posses de terras situadas nas extremidades não povoadas da capitania, tentando-se evitar extravios do ouro ao impossibilitar a abertura de novos caminhos e picadas nos matos em áreas onde inexistiam registros e vigilância das patrulhas ${ }^{4}$.

Enveredar-se em imensas regiões inóspitas ao redor das áreas urbanas da capitania era adentrar nos sertões ${ }^{5}$. Apesar de ser o local onde a natureza, detentora de um caráter ambíguo, tinha odores que exalavam "um hálito pestilento" e rios que só serviam de "bebedouros a monstros feios e dispersos bandos de bárbara gente que habitam suas sombrias margens," possuía rios dadivosos, de onde se extraiam: ouro, diamantes, esmeraldas, safiras e águas marinhas.

Na literatura setecentista, o sertão é apresentado sob perspectiva romantizada, evocado ora como um paraíso em que tudo era belo, justo, perfeito e estava em harmonia, não obstante habitado por seres que devoravam "animais da mesma espécie” (os indígenas) ${ }^{7}$; ora como um lugar de passagem, de travessia, definido pelo exercício da liberdade e pela dramaticidade da escolha de cada um que se embrenhava a fim de decifrar aquele ambiente fantástico, povoado por animais e plantas de todos os tipos, tamanhos e nomes.

Na prática, geograficamente, o sertão mineiro era a área recoberta principalmente pela zona curraleira — o "sertão dos currais" —, confinando a capi- 
tania de Minas Gerais com a da Bahia, entendida como "um extenso e aberto sertão", onde não existia atividade mineratória e as terras eram planas e vistosas, porém "menos férteis" do que a do restante do "continente de Minas."

Em Minas Gerais não havia somente um único sertão, mas vários ${ }^{9}$. As principais descrições indicam ser a região povoada por inúmeras nações indígenas e com fraca população branca. Na comarca do rio das Mortes, os sertões eram para os moradores das vilas de São José e São João del Rei os cerrados do alto São Francisco e as picadas de Goiás, como então se nomeavam as terras localizadas no caminho que levava para Vila Boa de Goiás. Para os que residiam na Borda do Campo, podiam ser as escarpas da Mantiqueira. A região da atual Zona da Mata era toda conhecida pelo nome de "sertões de leste," e entre 1768 e 1814, os assentos de batismo da atual cidade de Rio Pomba, localizada naquela paragem, eram abertos com a seguinte fórmula: Sertão do Rio da Pomba e Peixe dos Índios Cropós e Croatas. Além destes, para os homens de Vila Rica, os seus sertões eram as florestas cortadas pelo rio Doce e, para os moradores de Sabará, o médio São Francisco ${ }^{10}$.

Para a região da Mantiqueira, a visão de sertão associava-se aos diversos grupos indígenas que lá residiam: os coroados, carapós e puris; todos muito temidos e genericamente denominados botocudos, em virtude de uma espécie de botoque que os nativos daquela região usavam na boca e na orelha. Vencê-los, como às condições ambientais da mata Atlântica e à fauna que por lá vivia, era esforço para poucos. Percorrer os seus caminhos (ou como observavam as autoridades: os seus descaminhos), por tropeiros e vaqueiros que desciam e subiam suas rotas transportando gado e gêneros diversos, ou por "simples" viajantes que se dirigiam para as partes mais remotas da América portuguesa, era esforço sobre-humano. Um dado deve ser somado a essas dificuldades: a ação de salteadores que pelos caminhos andavam roubando e matando os viandantes ${ }^{11}$.

A região da Mantiqueira era um ponto nevrálgico na capitania, por ser área de fronteira "eriçada de morros elevadas e coberta de vegetação espessa, foi vista desde cedo o início da exploração aurífera como terreno propício ao descaminho e contrabando de ouro e pedras preciosas." Assim, desde o instante em que se abriu o Caminho Novo que ligava o Rio de Janeiro a Minas Gerais, no final do seiscentos, instalaram-se registros na serra por onde devia transitar qualquer comboio que saísse ou qualquer carregamento que entrasse em Minas. Com exceção dos sesmeiros estabelecidos ao longo daquela estrada, necessários ao abastecimento dos viajantes e à alimentação dos animais em trânsito - devido às roças que plantavam e aos pastos que mantinham —, nenhuma outra pessoa podia se fixar na região ${ }^{12}$.

Durante muitos anos, os "matos gerais" da Mantiqueira ficaram esqueci- 
dos pelas autoridades metropolitanas. Registra-se que em 1755, quando algumas pessoas teriam aberto picadas que cruzavam aqueles sertões, o governador interino José Antônio Freire de Andrada, 2o conde de Bobadela (17521758), publicou o Bando de 20 de setembro daquele ano, confirmando os sertões do "distrito da Mantiqueira" como área proibida.

No ano anterior, no mês de outubro, o então capitão Manuel Lopes de Oliveira, morador da fazenda da Borda do Campo, contígua ao sertão da Mantiqueira, representara ao mesmo governador notícias sobre a construção de três picadas feitas por "várias pessoas da freguesia da Borda do Campo", nos "matos gerais do Rio de Janeiro", com o "pretexto de necessária serventia para as suas fazendas". Como a abertura das picadas se avolumava naquelas paragens, o alferes João Carvalho de Vasconcelos, que patrulhava o Caminho Novo, repreendeu Manuel Lopes, que era o responsável por aquela área, para que "sem demora mandasse notificar as pessoas (...) para que não continuassem mais na abertura das ditas picadas" ${ }^{13}$.

A preocupação com os desvios era tanta que o mesmo alferes também notificou o capitão Sebastião Gonçalves Pinto a fim de que este parasse de incentivar a abertura de rotas alternativas nos sertões da Mantiqueira, da mesma forma que precedera contra Manuel Lopes de Oliveira. Ambos foram advertidos "para que as [picadas] não continuassem até ele governador [ $2^{\circ}$ conde de Bobadela] tomar sobre elas o conhecimento necessário, [com] pena de serem presos" $" 14$.

Essa medida paliativa por parte do alferes não adiantou nada, pois Manuel Lopes de Oliveira empreendeu política de expansão de terras na região, independentemente da proibição daqueles sertões.

A Coroa portuguesa considerava crime de lesa-majestade a abertura de vias de comunicação (que não fossem autorizadas pela metrópole), por recear o extravio dos quintos. Muitas vezes grupos de moradores tentaram abrir estradas à própria custa para facilitar o comércio e evitar a passagem pelos registros da capitania, onde eram feitos o controle de entrada e saída de pessoas e mercadorias e a cobrança dos impostos.

Ações individuais e coletivas permitiram a criação de desvios nos intrincados sertões da Mantiqueira. Incorporá-los aos espaços conhecidos e controlados da capitania correspondia a um processo de maior envergadura, que compreendia a interiorização da colonização, a conquista e a preservação dos territórios portugueses. Nesse contexto, o sertão, entendido como algo movediço e em constante alteração pela amplitude das explorações, se identificava com quatro grandes impulsos: o nordestino, voltado para a exploração do litoral açucareiro e que resultou na luta contra os holandeses; o nortista, voltado para a exploração da Amazônia; o sulista, até o Prata, tendo como pólo o Rio 
de Janeiro; e o paulista, de orientação centro-sul, devassando o interior da América do Sul - embrenhando-se nas escarpas da Mantiqueira, principalmente ${ }^{15}$.

O governador dom Rodrigo José de Meneses (1780-1783), recebendo informações sobre a ocupação descontrolada que ocorria naqueles sertões, da diminuição da arrecadação aurífera e dos boatos referentes aos extravios de ouro praticados nas infinitas picadas que cortavam de alto a baixo aquele local, mandou que se averiguasse a real situação daquela área vedada.

Procurando constatar as razões que levaram a tão descontrolada povoação, dom Rodrigo percebeu que a mesma se iniciou à custa do tenente-coronel Manuel Lopes de Oliveira, que "alucinara" (subornara) o governador interino José Antônio Freire de Andrada para ser publicado o bando de fechamento daquelas terras, de modo a "ficar sendo o único possuidor de todo o terreno que quisesse apropriar-se", para que pudesse "receber as utilidades e conhecer os intrincados caminhos", apossando-se das suas riquezas minerais ${ }^{16}$.

Essa mesma prática clandestina, apoiada nas atitudes de Manuel Lopes, que "soube pintar os danos que causaria abrir aquele sertão (...) fazendo todos os esforços enquanto viveu", foi seguida pelo seu genro José Aires Gomes, que desde os tempos do governador José Luís de Meneses Abranches Castelo Branco e Noronha, 6oㅡ conde de Valadares (1768-1773), usufrui as mesmas "utilidades" e os "intrincados caminhos" que cortavam os sertões da Mantiqueira, procurando afastar "toda a idéia de que nele houvesse ouro", a fim de impedir que as autoridades e os governadores devassassem a região em busca de novos regatos auríferos. Aires Gomes, quando soube de providências estatais para verificar a região, protestou junto ao governador conde de Valadares, convencendo-o a abandonar qualquer idéia desta natureza ${ }^{17}$.

Como o seu antecessor, José Aires Gomes conseguiu ludibriar as autoridades portuguesas durante alguns anos, mas não os "povos" que "se foram por aqueles sertões furtivamente introduzindo e [se] estabelecendo ocultamente". Com o assentamento constante de indivíduos na região, começaram a se formar "povoações" desordenadas. A exploração aurífera chegou "a tal ponto" de grandeza naquele local que dom Rodrigo José de Meneses, devido aos murmúrios que escutava, resolveu encaminhar àquela área Félix Vital Nogueira, intendente do ouro da comarca do Rio das Mortes, com a finalidade de verificar se interesses particulares sobrepunham-se aos dos povos e ao do império português ${ }^{18}$.

Ao receber a notícia que se minerava no córrego das Pedras, "lugar vedado para semelhante trabalho", o intendente se dirigiu àquela paragem. No local, passando "em vistoria", notificou os exploradores, comandados por João Homem da Costa, para se apresentarem a ele com as devidas ordens que lhes permitiam cultivar aquele veio aurífero. Os mineradores apresentaram-se e 
se constatou que aquele sítio de datas minerais se achava completamente "devassado, roçado e plantado e com paiol para recolher os frutos, fabricados por ordem do sargento-mor José Aires Gomes, que se diz senhor da dita terra, dada por sesmaria contra a mente de Sua Majestade" 19 .

Naquele córrego a produção chegava a ser de "três até quatro vinténs de ouro por jornal". Por informações de terceiros soube que o rio das Pedras desaguava nas cabeceiras do rio Paraibuna, local considerado pelas autoridades metropolitanas como área de fácil extravio de ouro, pois ficava a pouco mais de meia légua de soturnos caminhos. Preocupação verificada também nos "gerais de Santa Rita de Ibitipoca", onde

(...) se tem introduzido muita gente, devassando as áreas proibidas, com posses e serviços de minerar, cujo procedimento se faz digno de que Vossa Excelência lhe dê as providências de autoridade, (...) para coibir o arrojo de semelhantes homens que sem sujeição obram despoticamente. ${ }^{20}$

José Aires Gomes comandava a região, formada por "todo aquele globo da serra da Mantiqueira", composta por "matos gerais e impraticáveis, rodeados por uma parte do rio Preto e, por outra, pela estrada geral [Caminho Novo] que corre de Norte a Sul" ${ }^{21}$.

Observando a concentração de terras e a dificuldade em se controlar aquele sertão, o ajudante de ordens Félix Vital Nogueira indicou que a melhor solução para aquela situação irreversível seria repartir as terras agrícolas e minerais, pois isto poderia levar à diminuição dos descaminhos do ouro, uma vez que a região passaria a ser conhecida das autoridades, promovendo os régios interesses e permitindo a cobrança de impostos das lavras exploradas por aqueles moradores, além de desenvolver a agricultura de abastecimento.

Em seguida, o governador enviou aos sertões proibidos da Mantiqueira a expedição comandada pelo tenente-coronel Francisco Antônio Rebelo ${ }^{22}$. Partindo de Vila Rica em 17 de outubro de 1780, encaminhou-se aos sertões do ribeirão de Santa Rita, por ser ele, nas suas palavras, o de ocupação "mais freqüente." Deixemos que apresente as suas primeiras impressões do local:

(...)girei por ela abaixo seis léguas, por caminhos abertos e cultivados de arroz mais de três léguas, e dali para diante continua o mesmo caminho, pelo qual andam bestas carregadas conduzindo mantimentos até o rio do Peixe, que dista toda a estrada oito léguas. Em toda esta extensão que girei achei várias roças antigas e modernas; e me informaram que não só neste lugar, mas em sete estradas mais, que tem a referida serra, desde a Borda do Campo até a lagoa da Aiuruoca, aonde é também constante ser freqüente entrada, me certificaram acharam- 
se todos os referidos matos povoados por um número muito avantajado de moradores, os quais se comunicam por caminhos e picadas de uns para outros, com roças feitas, paióis e ranchos em que se recolhem." ${ }^{23}$

Para melhor conhecer e explorar a região, a fim de saber se as terras eram produtivas, a expedição contou com a ajuda de Antônio Tavares, um dos primeiros descobridores de ouro da região. Percorrendo as lavras existentes, entre os rios Pirapetinga e Pouso Alegre, que deságuam no rio do Peixe, vertente do rio Paraibuna, Antônio Tavares manifestou que ali extraiu a quantia de 222 oitavas e 4 vinténs de ouro (= $266 \$ 550$ réis) para si, e que cada um de seus agregados, sem especificar a quantidade de pessoas, tirou em média meia pataca de ouro por jornal (= 160 réis por dia $)^{24}$.

Ao continuar sua vistoria pelos sertões, foi parar no sítio de Manuel Correia, abaixo da foz do ribeirão das Imbarjaúbas, que deságua no ribeirão de Santa Rita, em lavras abertas e em pleno funcionamento. Mandou que "algumas pessoas inteligentes" que o acompanhavam fizessem provas da produção mineral daquele córrego. Constatou que o referido regato podia fazer jornal de quatro vinténs ao dia (= 150 réis). Os lavradores, na ocasião, mostraramlhe três embrulhos que continham ouro extraído: um de 15 oitavas, outro de 12 oitavas, e um terceiro de 11 oitavas, e tantos vinténs.

A população local, guiando-se pela crença de que a ruptura dos matos gerais fora devido ao exemplo de José Aires Gomes, que se tinha apossado de grande quantidade de terra e da riqueza mineral daquela paragem, também penetrou nos sertões proibidos da Mantiqueira. Ao mesmo era considerada a abertura de caminhos de carros e picadas pelos matos, por onde se seguia a cavalo do engenho de cana-de-açúcar - que construiu na saída da fazenda Mantiqueira - até o Caminho Novo, "cujas terras possui", e proibiu que todos os moradores daqueles sertões entrassem naqueles matos ${ }^{25}$.

Alguns dos residentes da estrada que ia do Rio de Janeiro a Vila Rica (Caminho Novo) tinham feito roças, paióis e aberto caminhos para dentro do sertão proibido, por onde poderia passar quem quisesse, sem encontrar a patrulha do mato - a responsável pela fiscalização do ouro e dos pedestres nos registros.

As informações sobre o devassamento e a exploração econômica dos sertões proibidos da Mantiqueira surpreenderam o governador dom Rodrigo, que resolveu se aventurar em semelhante empresa. O que levou essa autoridade portuguesa a arriscar-se a perigos sem fim nos sertões? As notícias sobre sua riqueza, onde se dizia existirem faisqueiras de bons rendimentos, e o desejo de reverter o quadro de retração econômica de Minas Gerais, através da descoberta de novos regatos auríferos, como melhorar a fiscalização e aumentar os rendimentos dos quintos, ajudam a elucidar a questão. 
ÁREA GEOGRÁFICA DOS SERTÕES DA MANTIQUEIRA

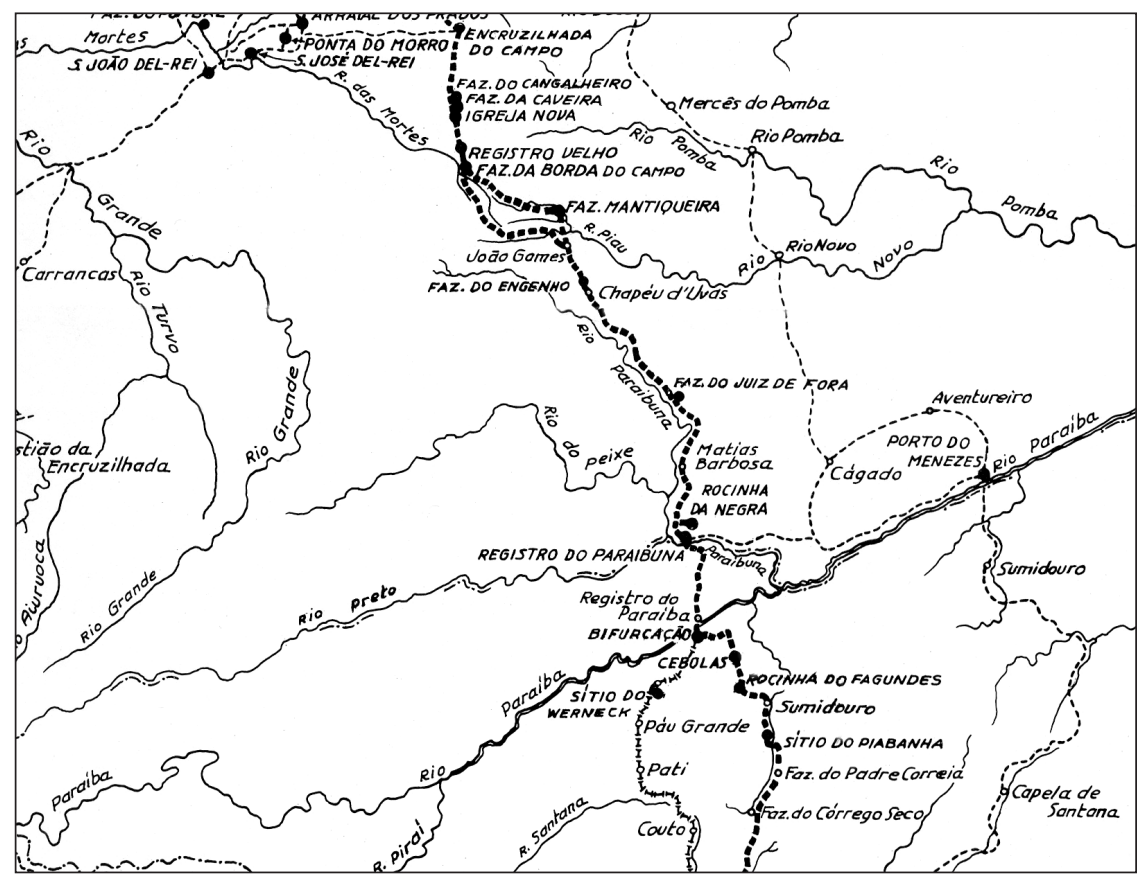

Fonte: Adaptado de Eduardo Canabrava Barreiros. "Área geográfica da inconfidência”. In Autos de Devassa da Inconfidência Mineira. 2. ed. Brasília: Câmara dos Deputados; Belo Horizonte: Imprensa Oficial, 1981, v. 3.

\section{"ABRINDO OS SERTÕES": A VIAGEM DO GOVERNADOR DOM Rodrigo José de Meneses E O “DEVASSAMENTO” DA MANTiQueira}

Em 1781, o governador dom Rodrigo José de Meneses percorreu as supostas “áreas vedadas dos sertões." Ele notou, como seus ajudantes, que a restrição ao povoamento daquela área não estava sendo cumprida. Ao tentar implantar novos limites entre a capitania mineira e a fluminense, através do rio Paraíba, que era de difícil transposição, encontrou aquele local devassado por mineradores e fazendeiros, estabelecidos com suas roças, paióis e moradias nos caminhos e picadas que entrecruzavam de alto a baixo aquelas paragens, por onde corria o ouro extraviado e a arrecadação da Fazenda Real2 ${ }^{26}$.

Diante da ocupação efetiva que se realizara furtivamente através dos anos, sem que os governadores anteriores desconfiassem dela, e as inúmeras vere- 
das e passagens ocultas que percorriam aquelas áreas por todos os lados, "sabidas por alguns indivíduos e desconhecidas pelo governo", assim como a "imensidade de pequenos negociantes que giram pelos caminhos de Minas", extraviando o nobre metal, dom Rodrigo decidiu repartir legalmente as terras de agricultura e as datas minerais com as pessoas que sem título algum as estavam possuindo e com outros indivíduos que se interessassem em desenvolver culturas, facilitada pela fertilidade do solo e riqueza das águas, tentando-se assim evitar a continuada sangria dos cofres da intendência do ouro ${ }^{27}$.

Foi neste sentido, o de unificar as regiões distantes com o centro administrativo da capitania, que o governador pensou ao propor a suspensão de tal medida que atrapalhava o desenvolvimento de Minas Gerais. Para ele, "debaixo da denominação de áreas proibidas", obtida "por meio de um abuso inveterado, que sem conhecimento de causa se tinha introduzido e por meios surdos e ruinosos para a Real Fazenda se tinha feito misteriosamente oculto", aquelas terras continuavam vedadas e servindo a uma minoria ${ }^{28}$.

A estratégia do governador com os mais de 280 moradores que se encontravam assentados na serra da Mantiqueira, propondo o ordenamento da região, enquadrava-se num contexto maior da política colonial portuguesa, que não era somente povoar as terras devolutas, mas transformar os seus habi262 tantes em bons vassalos, pagadores de tributos e laboriosos, conforme os interesses do Estado ${ }^{29}$.

A preocupação com a arrecadação e diminuição da cobrança dos quintos, sentida principalmente a partir da retração da extração aurífera na segunda metade do setecentos, levou dom Rodrigo José de Meneses a dedicar atenção à produção do ouro e à multiplicidade dos descobertos, que eram a "verdadeira felicidade das Minas Gerais." A busca por novos regatos minerais levou ao devassamento do território pelas autoridades, uma vez que uma das idéias principais dos régios interesses consistia "principalmente em extrair ouro da terra." ${ }^{30}$

Assim, interessava anexar o sertão à ordem colonial, penetrando, conhecendo e civilizando as áreas inóspitas, transformando-as em colônia. Nesse sentido, o sertão movia-se continuamente. Como personagem, o governador dom Rodrigo personificava-se como um lutador em sua saga contra o sertão, em luta contra os obstáculos humanos e naturais que retardavam a expansão da capitania.

A primeira viagem do governador aos "sertões incultos" da Mantiqueira ocorreu em 11 de junho de 1781, quando foi examinar a quantas andavam os descaminhos e a queda dos rendimentos do ouro - um dos principais problemas que então afrontavam a administração portuguesa.

Após sete dias de viagem, chegou à paragem Passa Três. Penetrando na 
"mata cinco léguas, encontrou vários mineiros, que manifestavam haver ouro no mesmo ribeirão, onde tomou o nome; e, fazendo-se o exame, presente o Ex. ${ }^{\text {mo }}$ General, se acharam faisqueiras, que bem asseguravam o jornal de 150 rs. [réis] por dia, a cada escravo." Neste local, nos contrafortes da Mantiqueira, José Aires Gomes, um dos grandes devassadores da região, possuía uma fazenda intitulada Passa Três, com extensão de "três léguas de terras de cultura, poucas em capoeiras e a maior parte de matos virgens", e que contava com cinco datas de águas minerais, além de campos que produziam milho. Contígua a esta propriedade, era dono de um sítio de nome semelhante (paragem Passa Três), de "meia légua de terras ainda incultas." Ao lado destas terras, possuía ainda a fazenda Engenho do Mato de São Sebastião (mais conhecida por fazenda Engenho), com plantações de milho, arroz e feijão; tudo coberto por quatro sesmarias (possivelmente cada uma tinha meia légua em quadra) ${ }^{31}$.

Daquele ponto, o governador continuou a sua viagem por mais três dias, até chegar às margens do rio do Peixe, que "desceu em pequenas canoas, passando por cima de muitos barrancos e cachoeiras de que é semeado até chegar ao abismo que o separa do rio Novo" (ribeirão de Piratininga), onde se arranchou, instalando-se por quatro dias, "dormindo no mato ao rigor do tempo, exposto à feracidade das feras". Naqueles "matos tão distantes de povoação", estabeleceu o seu quartel-general, onde repentinamente se achou formado um verdadeiro arraial, devido à concorrência numerosa do povo que o seguira para participar da distribuição das terras daquele quinhão de mundo ${ }^{32}$.

$\mathrm{Na}$ secretaria provisória de governo que instalou naquele sertão, recebeu mais de oitocentos requerimentos solicitando a repartição das terras agrícolas e minerais da Mantiqueira. Para que todas as petições fossem legalmente despachadas, o governador levou em sua expedição o ouvidor-geral da comarca de Rio das Velhas, o doutor Luís Beltrão de Gouveia e Almeida, para auxiliá-lo na árdua tarefa de atender a população ${ }^{33}$. Com o avançar dos dias e dos trabalhos, e com a finalidade de se oficializar a ocupação daquelas localidades, foram despachadas mais de trezentas cartas de sesmaria e muitas outras continuavam a ser recebidas. No rio do Quilombo, por exemplo, foram medidas 345 datas minerais; da cachoeira do Tavares até a foz deste mesmo rio foram demarcadas outras 422 datas minerais ${ }^{34}$.

É interessante observar que a população mais pobre, residente nos sertões proibidos, estaria excluída da repartição daquelas terras, uma vez que não possuía recursos para custear as despesas do processo de concessão nem escravos para trabalhar a terra, pois estes eram os requisitos necessários às doações das cartas de sesmaria. Para evitar qualquer mal-estar e balbúrdia que poderiam ser gerados entre as pessoas que o seguiram, o governador determinou que fosse distribuída, mediante requerimento, meia légua de terra 
de cultura às pessoas que comprovassem poder lavrá-las com seus próprios braços e com os de seus filhos e parentes (agregados).

O séquito que acompanhou dom Rodrigo José de Meneses às entradas que empreendeu pelos matos, chamado somente de "povo", permite-nos inferir que a ação desbravadora do governador rumo aos sertões proibidos e desconhecidos da Mantiqueira era uma tentativa de reafirmação da sociedade colonial, onde a civilização deveria ser levada a qualquer custo ao interior inóspito e bárbaro de Minas, habitado por silvícolas, quilombolas, negros fugidos e demais pessoas expurgadas da sociedade. A utilização de desclassificados, notadamente vadios e criminosos, nos projetos de integração dessas áreas à capitania, sinalizava a unidade simbólica do ordenamento jurídico e social que integraria o sertão à administração colonial ${ }^{35}$.

Quando penetrava pelos intrincados caminhos da serra, realizava experiências nos córregos que encontrava, a fim de localizar jazidas auríferas e descobrir a sua capacidade de exploração que, em maior ou em menor quantidade, revelavam-se prodigiosas e com razoável potencial econômico. Talvez o grande número de mineradores que encontrou em plena atividade extrativista e as várias petições que recebeu solicitando doações de terras agriculturáveis e minerais tenham levado o governador a subavaliar o metal precioso que descobriu naqueles córregos.

A permanência daqueles sertões como "área proibida”, de acordo com dom Rodrigo, não tinha razão para ser mantida, pois significava um procedimento destinado a desviar a atenção dos representantes metropolitanos do efetivo povoamento e devassamento que vinha ocorrendo na região, com "roças antigas e modernas" e com "caminhos abertos e cultivados" que levavam a qualquer parte daquele "globo." ${ }^{36}$

Essa ocupação irregular e ameaçadora do ponto de vista dos interesses administrativos coloniais, notadamente os verificados pelo governador, levou dom Rodrigo a observar, no final de sua expedição, que a manutenção daquela determinação era prejudicial aos interesses do reino, pois alimentava ainda mais os extravios auríferos, em vez de diminuí-los.

Antes de retornar a Vila Rica, dom Rodrigo determinou que se construísse uma nova estrada pelas margens setentrionais do rio Preto,

(...) que divide essa capitania da do Rio de Janeiro, e (...) se encontravam várias picadas por onde se suspeitavam passar, ou podiam passar extravios, o que tudo evitou com guardas e patrulhas, vindo assim a ficar acautelado qualquer descaminho; e, por isso, faculta e concede as sesmarias e datas, conforme as fábricas dos que a pedem. ${ }^{37}$ 
Assim, no sentido de abrir de vez o sertão, determinou a construção de uma estrada - o caminho de Meneses. O seu trajeto de leste para oeste atravessava a Mantiqueira e ia dar no registro do Paraibuna, depois de passar pelos vales dos rios do Peixe e Preto. Ficaram encarregados da construção o guarda-mor e tenente-coronel do segundo regimento de cavalaria auxiliar da comarca do rio das Mortes, Manuel do Vale Amado, um dos principais fazendeiros da Zona da Mata (sertões da Mantiqueira) e morador em Matias Barbosa, e o alferes Joaquim José da Silva Xavier, conhecido por Tiradentes, do destacamento do Caminho Novo ${ }^{38}$.

\section{CONSIDERAÇÕES FINAIS}

As viagens de dom Rodrigo José de Meneses, e anteriormente de seus auxiliares aos sertões proibidos da Mantiqueira, permite-nos detectar que a confluência de enormes distâncias, o poder de um grande proprietário de terras local - como se observou nas rápidas informações sobre a atuação de José Aires Gomes - e a inépcia de administradores produziram desordens na ocupação e no povoamento das áreas da Mantiqueira. Estes fatos ilustram sorrateiramente a dificuldade das autoridades em afirmar sua presença nos sertões, pois, à revelia da lei, homens como Aires Gomes e vários outros potentados locais adquiriram terras e mandavam no local, como se fossem seus verdadeiros donos, comandando econômica e politicamente aquelas paragens.

A apropriação das terras proibidas dos sertões da Mantiqueira é um exemplo da atuação de interesses privados na ordem pública. Seguindo o exemplo de José Aires Gomes, ao penetrar nas áreas vedadas, cultivar arroz, milho, feijão, cana-de-açúcar, entre outros produtos, além de criar gado vacum, "povos" foram "furtivamente" introduzindo-se naquelas paragens. Essa população pobre, muitas vezes tangida pelo refluxo do ouro, desenvolvia e estimulava constantemente a produção agrícola local e a procura por terras.

A doação de terras, especialmente as dos sertões, atendiam às específicas necessidades de mobilização e de produção de alimentos no interior de Minas Gerais. A viagem e as doações de terras realizadas pelo governador dom Rodrigo nos "desabridos" sertões da Mantiqueira nos permitem visualizar a existência de um forte movimento populacional no interior da capitania, na direção onde a atividade econômica crescia. A comarca do rio das Mortes, que congregava as terras dos sertões da Mantiqueira, no início do setecentos se desenvolveu como fonte de abastecimento da região mineradora e, a partir da segunda metade daquela centúria, passou também a manter intensas ligações com o Rio de Janeiro ${ }^{39}$. 


\section{NOTAS}

* Este artigo contém resultados parciais do segundo capítulo de nossa dissertação intitulada Um potentado na Mantiqueira: José Aires Gomes e a ocupação da terra na Borda do Campo. São Paulo, 2002. Dissertação (Mestrado em História Social) — FFLCH/USP, que contou com o apoio da Fundação de Amparo à Pesquisa do Estado de São Paulo (FAPESP).

' Sobre os primeiros anos de Minas Gerais, vale a pena conferir HOLANDA, Sérgio Buarque de. "Metais e pedras preciosas". In HOLANDA, Sérgio Buarque de (dir.). História geral da civilização brasileira: a época colonial. Rio de Janeiro: Bertrand Brasil, 1997, v. 1, t. 1, pp. 259-310; VASCONCELOS, Diogo de. História antiga de Minas Gerais. 4. ed. Belo Horizonte: Itatiaia, 1974, v. 1, pp. 141-161.

${ }^{2}$ Sobre os estudos recentes que vêm mostrando que havia uma certa complementaridade entre as mercadorias importadas e as produções locais, ver RODRIGUES, André Figueiredo. Um potentado na Mantiqueira: José Aires Gomes e a ocupação da terra na Borda do Campo. São Paulo, 2002. Dissertação (Mestrado em História Social) — FFLCH/USP, e a bibliografia ali citada e comentada.

${ }^{3}$ A região da serra da Mantiqueira que atinge São Paulo e Bahia com as denominações Paranapiacaba, Cantareira, Chapada Diamantina, serra do Tombador e serra da Jacobina, somente em Minas Gerais adquiriu a denominação geral: Mantiqueira. Este termo tem a sua origem na língua tupi e significa "serra das vertentes", pois Maan - coisa grande, serra e Tiquira - que verte. Conferir: "Discurso de posse — Jorge Lasmar." Revista do Instituto Histórico e Geográfico de Minas Gerais. Belo Horizonte, v. 22, t. 1, p. 717, 1992-1998; COSTA, Joaquim Ribeiro. “Mantiqueira." In Toponímia de Minas Gerais. 2. ed. rev. Belo Horizonte: BDMG Cultural, 1997, p. 273.

${ }^{4}$ Arquivo Público Mineiro. Seção Colonial, Códice 224, fl. 29. Devo à Prof. ${ }^{a}$ Dr. ${ }^{\underline{a}}$ Laura de Mello e Souza a indicação desta interessante documentação.

${ }^{5}$ A palavra sertão advém do termo latino desertanum, desertum. No português antigo se falava desertão para designar lugar desconhecido, solitário, seco e não entrelaçado ao conhecimento. Imaginou-se sertão também como a terra apartada do mar, mediterrânea, continental no sentido em que se empregava a palavra em Portugal no final da Idade Média: era a terra para lá das costas ao longo das quais se navegava. Com esses significados, desde a carta de Pero Vaz de Caminha e ao longo de três séculos de colonização, o conceito sertão foi empregado para designar a terra ignota do continente, "o coração das terras", por vezes lugar sombrio e incompreensível, habitado por feras e seres inimagináveis e onde se esperava encontrar riquezas incalculáveis. Conferir: AULETE, Caldas. "Sertão." In Dicionário contemporâneo da língua portuguesa. 2. ed. Rio de Janeiro: Delta, 1964, v. 5, p. 3.720; BLUTEAU, Raphael. “Sertão." In Dicionário da língua portuguesa. Lisboa: Oficina de Simão Thaddeo Ferreira, 1789. Este mesmo significado pode ser encontrado em SILVA, Antonio Moraes. "Sertão." In Diccionario da lingua portugueza. Rio de Janeiro: Officinas da S. A. Litho-Typografia Fluminense, 1922, p. 693. 
${ }^{6}$ ROCHA, José Joaquim da. Geografia histórica da capitania de Minas Gerais. Belo Horizonte: Fundação João Pinheiro, 1995, p. 83; COUTO, José Vieira. Memória sobre a capitania das Minas Gerais. Belo Horizonte: Fundação João Pinheiro, 1994, p. 80; VASCONCELOS, Diogo Pereira Ribeiro de. Breve descrição geográfica, física e política da capitania de Minas Gerais. Belo Horizonte: Fundação João Pinheiro, 1994, p. 53.

${ }^{7}$ VASCONCELOS, Diogo Pereira Ribeiro de. op. cit., p. 157.

${ }^{8}$ COELHO, José João Teixeira. Instrução para o governo da capitania de Minas Gerais. Belo Horizonte: Fundação João Pinheiro, 1994, pp. 239, 60, 192.

${ }^{9}$ A variedade de sertões em Minas Gerais foi estudada por Laura de Mello e Souza em Famílias de sertanistas: expansão territorial e riqueza familiar em Minas na segunda metade do século XVIII. 1998, pp. 15-16 (mimeo).

${ }^{10}$ CARRARA, Ângelo Alves. “O 'sertão' no espaço econômico da mineração.” LPH: Revista de História, Mariana: UFOP; ANPUH-MG, n. 6, pp. 40-48, 1996; SOUZA, Laura de Mello e. Família de sertanistas..., op. cit., pp. 15-16; CASTRO, Celso Falabella de Figueiredo. Os sertões de Leste: achegas para a história da Zona da Mata. Belo Horizonte: Imprensa Oficial, 1987.

${ }^{11}$ Júnia Furtado conta-nos as aventuras e medos passados pelos comerciantes nas suas andanças pelos caminhos que ligavam os centros urbanos de Minas Gerais ao litoral fluminense e às suas áreas interioranas. Analisando testamentos de diversos viandantes, demonstrou-se que os que se dedicavam ao comércio fixo se dispunham a fazer os seus testamentos na sua fase terminal, quando estavam já no seu leito de morte. Por outro lado, os comerciantes errantes, devido aos perigos e incertezas das viagens, deixavam de antemão as suas vontades declaradas. Conferir: FURTADO, Júnia. Homens de negócio. São Paulo: Hucitec, 1999, pp. 98-99. Sobre as quadrilhas que assolavam os caminhos mineiros, ver: VASCONCELOS, Diogo de. “A Mantiqueira.” In História média das Minas Gerais. 4. ed. Belo Horizonte: Itatiaia, 1974, pp. 261-276; SOUZA, Laura de Mello e. Desclassificados do ouro. 3. ed. Rio de Janeiro: Graal, 1990, pp. 199-202; ANASTASIA, Carla. "Salteadores, bandoleiros e desbravadores nas matas gerais da Mantiqueira (1783-1786).” In PRIORE, Mary del (org.). Revisão do paraíso. Rio de Janeiro: Campus, 2000, pp. 115-138.

${ }^{12}$ SOUZA, Laura de Mello e. Famílias de sertanistas..., op. cit., p. 5.

${ }^{13}$ Arquivo Público Mineiro. Seção Colonial, Códice 224, fl. 35.

${ }^{14}$ Idem.

${ }^{15}$ ABREU, Capistrano de. Capítulos de história colonial. 7. ed. rev. Belo Horizonte: Itatiaia; São Paulo: Edusp, 1988, pp. 117-216; MAGALHÃES, Basílio de. Expansão geográfica do Brasil colonial. 3. ed. ampl. Rio de Janeiro: EPASA, 1944, pp. 267-372; HEMMING, John. “Os índios e a fronteira no Brasil colonial.” In BETHELL, Leslie (org.). História da América Latina colonial. Trad. de Mary Amazonas Leite de Barros e Magda Lopes. São Paulo: Edusp; Brasília, DF: Fundação Alexandre de Gusmão, 1999, pp. 426-469; IGLÉSIAS, Fran- 
cisco. Trajetória política do Brasil: 1500-1964. São Paulo: Companhia das Letras, 1993, pp. 44-50.

${ }^{16}$ Arquivo Público Mineiro. Seção Colonial, Códice 224, fls. 29-30v. Laura de Mello e Souza foi quem chamou a atenção sobre o fato do governador ter sido "alucinado" por Manuel Lopes de Oliveira, para que sozinho usufruísse as terras da Mantiqueira. Conferir: Família de sertanistas..., op. cit., pp. 5-6.

${ }^{17}$ Arquivo Público Mineiro. Seção Colonial, Códice 224, fl. 30v. O contratador de entradas e dízimos João Rodrigues de Macedo, em carta datada de 31 de outubro de 1780, indagara a posição assumida por Aires Gomes no controle dos caminhos: "Não sei que motivo tenha Vossa Mercê para não cumprir inteiramente com as ordens dos Senhores Generais [com] respeito a fazer fraquear os caminhos e estradas." In OLIVEIRA, Tarquínio J. B. de. Correspondência ativa de João Roiz de Macedo. Ouro Preto, MG: ESAF; Centro de Estudos do Ciclo do Ouro; Casa dos Contos, 1981, v. 2, p. 167 (carta 694).

${ }^{18}$ Arquivo Público Mineiro. Seção Colonial, Códice 224, fl. 30v.

${ }^{19}$ Idem, fls. 36-36v.; SOUZA, Laura de Mello e. Família de sertanistas..., op. cit., p. 5.

${ }^{20}$ Arquivo Público Mineiro. Seção Colonial, Códice 224, fl. 36v.

${ }^{21}$ Idem, fl. 38.

${ }^{22}$ O escrivão e contador da Real Fazenda, Francisco Antônio Rebelo (1731-1805), é mais conhecido por ser o autor do Erário Régio de Sua Majestade Fidelíssima, ou somente Erário Régio, de 1768. Nesta obra analisa a origem e a evolução dos tributos reinóis que incidiam sobre a capitania de Minas Gerais: os dízimos, as entradas, as passagens de rios, os ofícios de justiça, as propinas e a cera para luminárias nas festas reais e os rendimentos da provedoria da Real Fazenda do ano de 1767.

${ }^{23}$ Arquivo Público Mineiro. Seção Colonial, Códice 224, fl. 38v.

${ }^{24}$ Idem.

${ }^{25}$ Idem, fl. 39.

${ }^{26}$ SOUZA, Laura de Mello e. Família de sertanistas..., op. cit., p. 5.

${ }^{27}$ COELHO, José João Teixeira. op. cit., p. 204.

${ }^{28}$ Arquivo Público Mineiro. Seção Colonial, Códice 224, fls. 20-20v.

29 “A política pede [que] se conservem vassalos laboriosos, que não carregam o país com o peso da sua inutilidade, antes pelo contrário trabalham para o bem comum”. In: idem, fl. 31.

${ }^{30}$ Arquivo Público Mineiro. Seção Colonial, Códice 211, fl. 30. Conferir, também: BARBOSA, Waldemar de Almeida. História de Minas. Belo Horizonte: Comunicação, 1979, v. 3, pp. 612-618; RESENDE, Maria Efigênia Lage de. “Estudo crítico.” In ROCHA, José Joaquim da. op. cit., p. 53.

${ }^{31}$ ROCHA, José Joaquim da. op. cit., p. 190; Instituto Histórico e Geográfico Brasileiro. “Tras- 
lado de auto de seqüestro feito em bens do coronel José Aires Gomes." Igreja Nova (Barbacena). Maio/junho de 1791, fls. 21-26v. De acordo com o desembargador José João Teixeira Coelho, intendente do ouro da Casa de Fundição de Vila Rica e que serviu na secretaria de governo a quatro governadores (1767-1779), as sesmarias "são as porções das terras ou matos maninhos e bravos pertencentes a Sua Majestade que nunca foram lavrados, nem aproveitados e que se concedem a sesmeiros que as rompam, lavrem e semeiem para que haja abundancia de mantimentos." In COELHO, José João Teixeira. op. cit., p. 246. De forma ilustrativa, a fazenda Passa Três, de três léguas por uma, tinha 130,68 km_ou 130.680 .000 $\mathrm{m}_{\text {. }}$ Conferir, sobre os cálculos dimensionais de uma sesmaria, BARBOSA, Waldemar de Almeida. A decadência das Minas e a fuga da mineração. Belo Horizonte: Imprensa da UFMG, 1971, p. 44.

${ }^{32}$ Eis a interessante narração do arraial que se formara naquelas paragens: "um arraial numeroso, composto do muito povo que me tinha seguido para participar da repartição das terras (...) e imediatamente entraram na secretaria mais de oitocentos requerimentos e ficaram logo concedidas trezentas e tantas sesmarias, que depois se tem ido aumentando com novos requerimentos legalizados." In Arquivo Público Mineiro. Seção Colonial, Códice 224 , fls. $61 \mathrm{v}-62$.

${ }^{33} \mathrm{Na}$ época da Conjuração Mineira, Luís Beltrão de Gouveia e Almeida ocupava o mais alto cargo no Distrito Diamantino, que era um território "fechado" dentro da capitania de Minas Gerais, ao redor da vila do Tejuco (atual Diamantina). Conferir: JARDIM, Márcio. A Inconfidência Mineira: uma síntese factual. Rio de Janeiro: Biblioteca do Exército, 1989, p. 208.

${ }^{34}$ Arquivo Público Mineiro. Seção Colonial, Códice 224, fl. 62. As datas minerais concedidas em Minas Gerais eram áreas de 30x30 braças, correspondendo cada braça a 1,10 metro. Só eram concedidas terras minerais a quem tivesse pelo menos 12 escravos de trabalho para as lavras. Além disso, concediam-se frações de 2,5x2,5 braças por escravo, a quem tivesse menor número de trabalhadores. Era praxe, de outro lado, não se conceder segunda data a quem não houvesse provado explorar a primeira e contar com mais escravos para a próxima. Sobre a legislação de minas e as concessões de datas de águas minerais, vale a pena conferir ESCHWEGE, Wilhelm L. von. Pluto brasiliensis. Belo Horizonte: Itatiaia; São Paulo: Edusp, 1979, v. 1, pp. 83-132.

${ }^{35}$ SOUZA, Laura de Mello e. Desclassificados do ouro, op. cit., pp. 71-90; Idem. Norma e conflito. Belo Horizonte: Ed. UFMG, 1999, pp. 83-110.

${ }^{36}$ Arquivo Público Mineiro. Seção Colonial, Códice 224, fls. 38v; 38.

${ }^{37}$ ROCHA, José Joaquim da. op. cit., p. 191.

${ }^{38}$ Arquivo Público Mineiro. Seção Colonial, Códice 224, fls. 63; 66v-70. A escolha do alferes Tiradentes não foi aleatória, pois, naquele mesmo ano, entregou o caminho entre Sete Lagoas e Paracatu, que providenciou, desobrigando os viandantes de um contorno geográfico que ia quase às fronteiras de São Paulo no acesso a Goiás. Conferir: OLIVEIRA, Tarquí- 
nio J. B. de. "Introdução." In Correspondência ativa..., op. cit., v. 2, p. 3. A construção deste caminho e as atividades de Tiradentes na região do porto do Meneses não serão explicitadas aqui, pois aparecerão em outro artigo.

${ }^{39} \mathrm{O}$ crescimento verificado no interior das Minas Gerais, mais especificamente no da região da Borda do Campo - comarca do Rio das Mortes —, constitui um dos eixos temáticos de nossa dissertação. Conferir: RODRIGUES, André Figueiredo. op. cit.

Artigo recebido em 7/2003. Aprovado em 10/2003.

Revista Brasileira de História, vol. 23, nº 46 